\title{
Effect of Lignin Content on Direct Liquefaction of Bark
}

\author{
Tomoaki Minowa, Tomoko Ogi, Yutaka Dote \\ and Shin-ya Yokoyama
}

National Institute for Resources and Environment, Tsukuba 305

\begin{abstract}
Key Words : Biomass, Bark, Lignin, Liquid Fuel, Direct Liquefaction, Steam Explosion
The effect of lignin content on the direct liquefaction of bark was examined. Six kinds of barks having different lignin content were liquefied by a steam explosion method and an autoclave method. With increasing lignin content, the oil yield decreased and the char yield increased. The oil yield by the steam explosion method was higher than that by the autoclave method and the char yield by the former was lower than that by the latter. Although lignin leads to the formation of char by condensation or repolymerization, the steam explosion would retard the reaction.
\end{abstract}

\section{奥行きを粒子一層とした気固系流動層の気泡流動特性 ${ }^{\dagger}$ \\ 幡野博之*·楊 栄華・石田 愈 \\ 東京工業大学 資源化学研究所 ${ }^{\dagger \dagger}$}

\section{緒言}

気固系流動層の流動特性は系が不透明であるととから， 著者らを含め一般に，新しい原理に基づいたプローブを 開発したり，2次元流動層を用いて検討されてきだ”。 かし，プローブでは局所の情報しか得られず，また， 2 次元流動層では壁付近の粒子により気泡や着目粒子の動 きが隠されて完全に追跡するてとは難しかった．そのた め, 気泡や粒子の動きを完全に追跡できる粒子一層の奥 行きを有する 2 次元流動層 ${ }^{31}$ を開発した。

本研究では本装置内の気泡径や気泡上昇速度をビデオ システム ${ }^{3)}$ で詳細に測定し，通常の奥行きを有する 2 次 元流動層で測定した気泡上昇速度や，乙れまで 2 次元や 3 次元流動層に適用されてきた氛泡径推算式と比較した。

\section{1. 実験装置および方法}

\section{$1 \cdot 1$ 実験装置}

本研究で使用した実験装㯰の概略をFig. 1 亿示す。装

† 1991年 3 月27日受理 ; 化学「学会第 23 回秋季大会 (金沢, 1990年10月）にて一部発表

†† 227 横浜市緑区長津田 4259

* 資源環境技術総合研究所
置本体は 2 枚の厚さ $5 \mathrm{~mm}$ のガラス板で高さ $600 \mathrm{~mm}$, 幅 $200 \mathrm{~mm}$ である。 スペーサは幅 $5 \mathrm{~mm}$, 厚さ $1.0 \mathrm{~mm}$ の軟 質塩化ビニール製であるが，ガラス板でスペーサをはさ む際に微妙な隙間が生じるため，流動化領域の奥行きは $1.2 \mathrm{~mm}$ である。また，高さと幅はそれぞれ $600 \mathrm{~mm}$ と $180 \mathrm{~mm}$ である. 分散板として, 孔径 $0.7 \mathrm{~mm}$ の孔をピッ チ $5 \mathrm{~mm}$ で35個直線上に並べた多孔板を用い, 直径 $1 \mathrm{~mm}$ の鉄粒子を $50 \mathrm{~mm}$ の高さまで積み重ねて空気が均一に流 れるようにしている.ブロワーからの空気は粒子の帯電 を防ぐため加湿器を通し, 分散板下部の風箱に供給して いる．本研究で使用したビデオシステムの詳細について は別報にゆずる゙!.

\section{2 使用粒子と実験条件}

実験に使用した粒子は平均径が $1.0 \mathrm{~mm}$ のガラスビー ズである．粒子径分布は単峰性でその幅は非常に狭い。 粒子密度は $2.53 \times 10^{3} \mathrm{~kg} / \mathrm{m}^{3}$, 実測した最小流動化速度 $U_{m f}$ は $0.98 \mathrm{~m} / \mathrm{s}$ である. 静止層高は $0.20,0.25,0.30 \mathrm{~m}$, ガス流速は $U_{m f}$ の $1.25,1.38,1.64,1.81$ 倍の 4 種類で検 討した。 


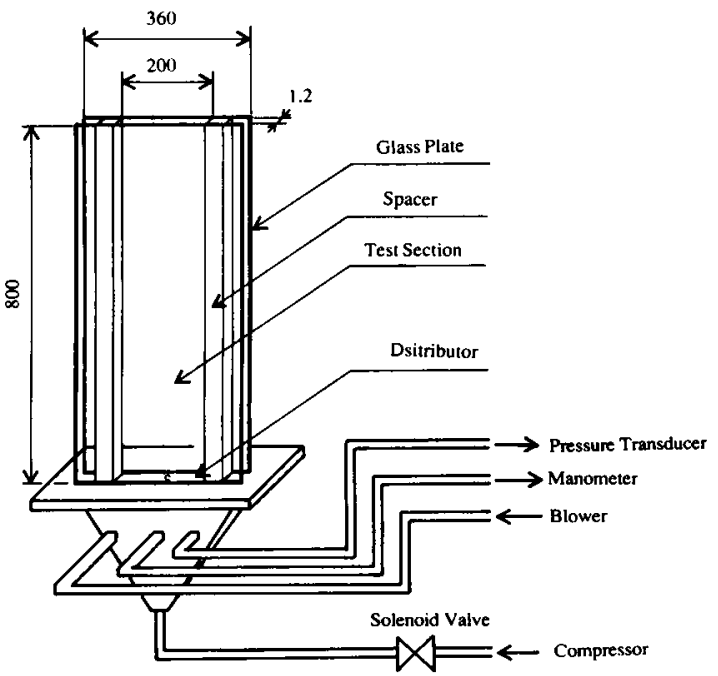

Fig. 1 Outline of experimental apparatus

\section{2. 実験結果と考察}

Fig. 2 にガス流速を変えた時の流動層内の様子を示す． (a) は $U_{o}=1.23 \mathrm{~m} / \mathrm{s}$ の時の例で，本装置においても，ス フェリカルキャップに近い形状の気泡が観察される. (b) は $U_{0}=1.35 \mathrm{~m} / \mathrm{s}$ とガス流速を増した時の例で，(a)と較 べると気泡が大きくなっいる，(c) は $U_{0}=1.61 \mathrm{~m} / \mathrm{s}$ ま でガス流速を増した時の例で，(b)よりも気泡の成長が 著しく，非常に大きな気泡が現われる，気泡間の干渉が 大きくなるため不規則な形状の気泡が增えている．３次 元流動廉においても同様な気泡形状が観察されている”. （d）は $U_{0}$ を $1.78 \mathrm{~m} / \mathrm{s}$ とした時の例で，気泡会合が非常 に激しく生じ，空隌が連続相に近くなっている.

Fig. 3 にガス流速, 分散板からの高さと気泡径との関 係を示す，図中，白拔きの記号は平均值を表している. 実線は傾き 1 で平均值と良く一致している，また，一点 鎖線は標準偏差の幅を表している，一方，3 次元装置で 求められた気泡径推算式 Eq. (1) ${ }^{2)}$

$$
D_{B}=1.1\left(U_{o}-U_{m f}\right)^{0.6} L_{d}{ }^{0.6} D^{0.1} / K_{B}{ }^{0.6} g^{0.3} \text { (1) }
$$

に後の奏験結果から得る $K_{B}=0.44$ を使用すると図中の 実線となる．ガス流速が遅い場合や分散板からの高さが 低い場合には実測された気泡径のばらつきは比較的小さ い，しかし，ガス流速が大きい場合や層上部では，会合 しない気泡や分裂する気泡が増えるため，小さな気泡が 多く見られる、そのため，平均值む小さくなり，データ のばらつきも增す。このような小さな気泡を除けば，奥 行きが粒子一層という極度に薄い流動層ではあるが, 気 泡成長は Eq. (1) で推算でき，ガス流速，分散板からの 高さの影響は 3 次元装置と变わらないといえる.

Fig. 4 亿本装置で測定された気泡径と気泡上昇速度と

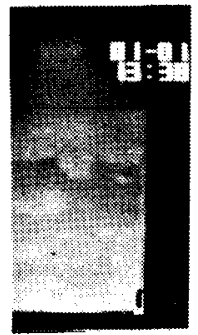

(a)

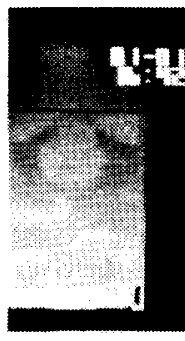

(b)

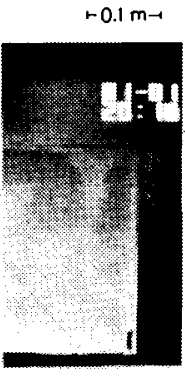

(c)

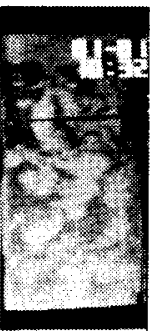

(d)
Fig. 2 Typical photographs of bubble rising in singlelayer fluidized bed. (a) $U_{o}=1.23 \mathrm{~m} / \mathrm{s}$, (b) $U_{o}=$ $1.35 \mathrm{~m} / \mathrm{s}$, (c) $U_{o}=1.61 \mathrm{~m} / \mathrm{s}$, and (d) $U_{o}=1.78 \mathrm{~m} / \mathrm{s}$

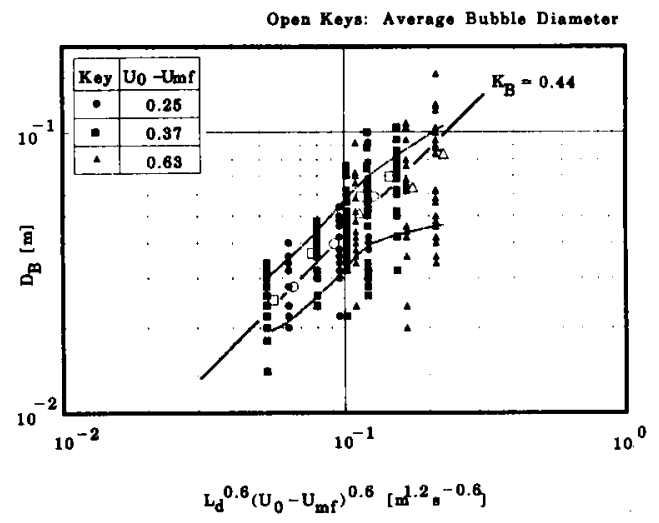

Fig. 3 Comparison of observed bubble diameter with those calculated

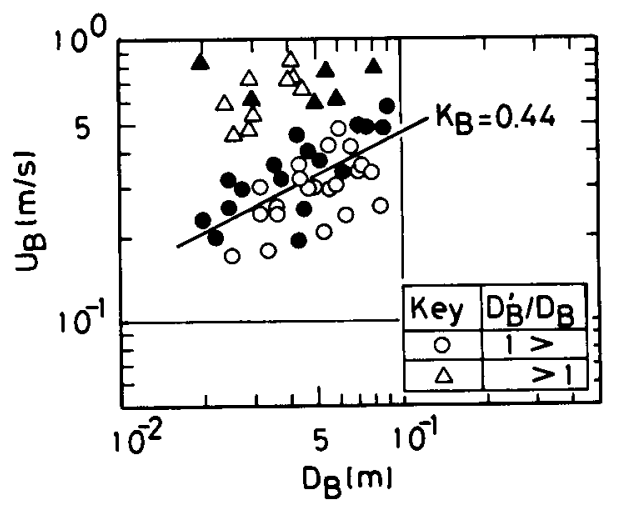

Fig. 4 Relation between $D_{B}$ and $U_{B}$. (,$\wedge$ : data for $0.40 \mathrm{~mm}$ diameter glass beads in $10 \mathrm{~mm}$ width 2 -dimensional bed)

の関係を示す，気泡アスペクト比（気泡高さ/気泡径） が 1 以下で気泡間の干涉が少ない独立気泡と，会合途中 でアスペクト比が1より大きくなっている干涉気泡に分 げ，前者を○で，後者を $\triangle$ で表している，また，気泡 アスペクト比は多少大きくなっているが，奥行きが 10 
$\mathrm{mm}$ の 2 次元流動層で平均径が $0.40 \mathrm{~mm}$ のガラスビーズ

を流動化した際に求めたデータを同図上に黒抜きの記号

で示す。乙の場合の $K_{B}$ は 0.50 と求められた。 てのよう

に奥行きが一層の流動層では, 独立気泡, 干渉気泡とも

に気泡上.昇速度は 2 次元流動層之同程度といえる. 特に

独立気泡に対する $K_{B}$ は 0.44 と求められる. 3 次元流動

層でも同様な独立気泡と干渉気泡との関係はみられ ${ }^{11}$,独 立気泡に対しては 0.71 , 干涉気泡に対しては最大で 2

2.5 程度の大きな $K_{B}$ が得られている.

\section{Nomenclature}

$D$ = bed width or bed diameter

$[\mathrm{m}]$

$D_{B}=$ bubble diameter

$$
\begin{aligned}
& \mathrm{g}=\text { gravitational acceleration } \\
& {\left[\mathrm{m} / \mathrm{s}^{2}\right]} \\
& K_{B}=U_{B} /\left(g \cdot D_{B}\right)^{1 / 2} \\
& L_{d}=\text { height from gas distributor } \\
& {[-]} \\
& L_{m f}=\text { bed height at } U_{m f} \\
& {[\mathrm{~m}]} \\
& U_{0}=\text { superficial gas velocity } \\
& {[\mathrm{m}]} \\
& U_{B}=\text { bubble rise velocity } \\
& {[\mathrm{m} / \mathrm{s}]} \\
& U_{m f}=\text { gas velocity at minimum fluidization }
\end{aligned}
$$

\section{Literature cited}

1) Hatano, H., IAH Khattab, K. Nakamura and M. Ishida: J. Chem. Eng. Japan., 19, 425 (1986)

2) Hirama, T., M. Ishida and T. Shirai: Kagaku Kogaku Ronbunshu, 1, 272 (1975)

3) Ichikawa, Y., H. Hatano, C. Kuroda and M. Ishida: Kagaku Kogaku Ronbunshu, 17, 1062(1991)

\title{
Flow Characteristics of Bubbles in a Single-Layer Gas-Solid Fluidized Bed
}

\author{
Hiroyuki Hatano*, Ronghua Yang and Masaru Ishida
}

Research Laboratory of Resources Utilization, Tokyo Inst. of Tech., Yokohama 227

Key Words : Fluidization, Single-Layer Particle System, Visualization, Gas-Solid System, Bubble Behavior

A single-layer gas-solid fluidized bed is developed by setting two glass plates vertically with a spacing space of which is slightly greater than the diameter of the particles. The behavior of gas bubbles is observed in detail by introducing high shutter-speed video cameras with $1 / 2000 \mathrm{~s}$ exposure time and an image analyzer.

It is found that the rising velocity of bubbles in the single-layer fluidized bed is almost the same as that in the ordinary two-dimensional fluidized bed. The effect of gas velocity and height from the distributor on bubble growth is almost the same as in the three-dimensional fluidized bed despite its extremely small bed width.

* National Institute for Resources and Environment 